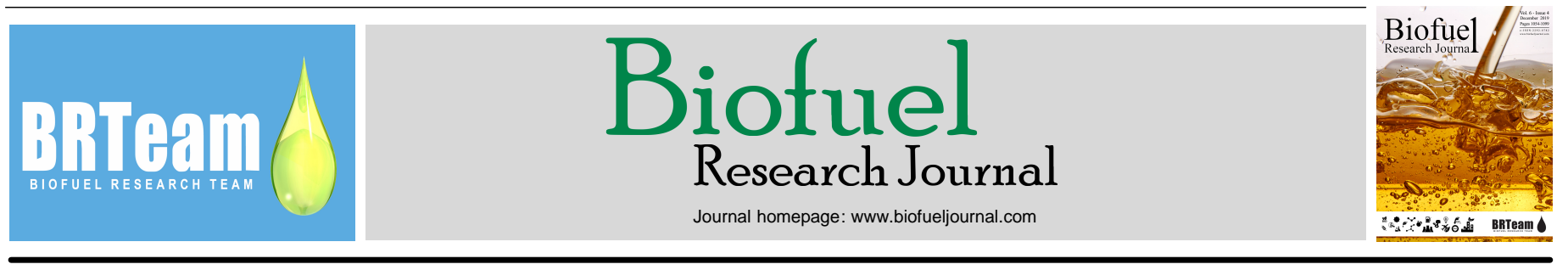

Review Paper

\title{
Comparison of pretreatment methods that enhance biomethane production from crop residues - a systematic review
}

\author{
Reckson Kamusoko $^{1, *}$, Raphael Muzondiwa Jingura ${ }^{1}$, Wilson Parawira ${ }^{2}$, Walter Tendai Sanyika ${ }^{1}$
}

${ }^{1}$ Chinhoyi University of Technology, P. Bag 7724, Chinhoyi, Zimbabwe.

${ }^{2}$ Bindura University of Science Education, P. Bag 1020, Bindura, Zimbabwe.

\section{HIGHLIGHTS}

$>$ Efficacy of biological, chemical, physical and combined pretreatments in enhancing biomethane production from crop residues compared.

$>$ Physical and chemical pre-treatment methods are the most effective and fastest.

$>$ Disadvantages of physical and chemical pretreatments are high cost of resources, operation and energy as well as formation of inhibitory byproducts.

$>$ Combined pretreatment processes are fast and costeffective but have limited utility due to generation of toxic compounds.

$>$ Biological pretreatment is inexpensive, eco-friendly and low energy-consuming process.

\section{GRAPHICAL ABSTRACT}

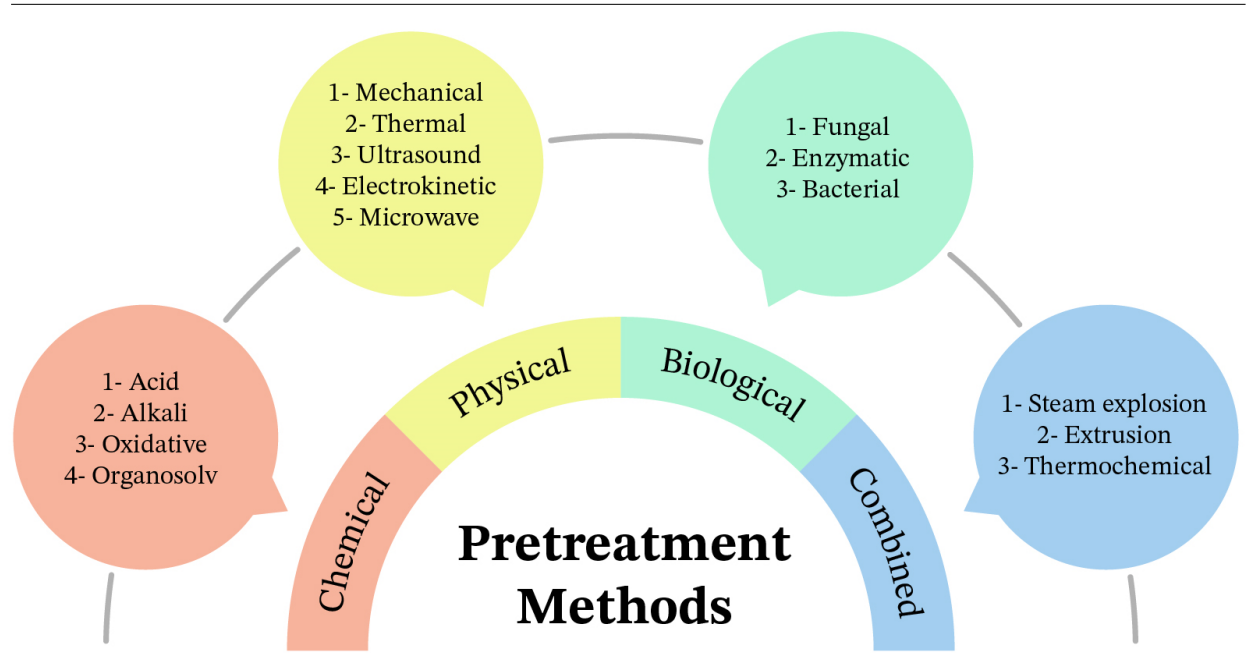

\section{ARTICLE INFO}

\begin{abstract}
ABSTRACT

A systematic literature review was conducted to compare the efficacy of biological, chemical, physical, and combined pretreatments in enhancing biomethane production from crop residues (CR). Three electronic databases viz., Science Direct, EBSCOhost, and PubMed were used to identify the studies in literature. The pretreatment methods were compared in terms of their advantages and disadvantages with reference to techno-economic aspects. The techno-economic aspects considered included rate of hydrolysis, energy use, effectiveness, cost, and formation of toxic compounds. A total of 3167 studies, covering the period $2014-2018$, were screened for relevance to the study. Forty-four records $(n=44)$ consisting of 36 research papers $(n=36)$ and eight narrative reviews $(n=8)$ met the inclusion criteria. The results show that physical and chemical methods are the most effective and fastest. These methods have limited utility due to high cost of resources, operation, and energy as well as formation of inhibitory by-products. Despite generation of toxic compounds, combined methods are regarded as fast and costeffective. Biological method is inexpensive, eco-friendly, and low energy-consuming. However, it is a nascent technology that is still developing. A combination of trends in research and development provide the best pretreatment alternative to improve the biomethane production from $\mathrm{CR}$.
\end{abstract}

Article history:

Received 6 October 2019

Received in revised form 18 November 2019

Accepted 18 November 2019

Available online 1 December 2019

\section{Keywords:}

Anaerobic digestion

Biogas

Biomethane potential

Feedstock

Organic matter

(C) 2019 BRTeam. All rights reserved.

* Corresponding author at: Tel.: +263 $672122203-5$

E-mail address: rkamsoko.kamusoko@gmail.com

Please cite this article as: Kamusoko R., Jingura R.M., Parawira W., Sanyika W.T. Comparison of pretreatment methods that enhance biomethane production from crop residues - a systematic review. Biofuel Research Journal 24 (2019) 1080-1089. DOI: 10.18331/BRJ2019.6.4.4 


\section{Introduction}

Biogas is a renewable fuel with wide applications the world over (Weiland, 2010; Achinas et al., 2017; Alhassan et al., 2019). Over 60.8 billion $\mathrm{m}^{3}$ of biogas are produced annually in the world (WBA, 2018). WBA data show that biogas production is increasing throughout the world. Global biogas production increased 3.7 times from $0.28 \mathrm{EJ}$ to $1.31 \mathrm{EJ}$ during 2000 to 2016 (WBA, 2018). Almost $54 \%$ of biogas is produced in the Europe. Africa accounts for only $0.03 \%$ of the annual global biogas production (WBA, 2018), yet it has vast resources for biogas production. Biogas is produced by anaerobic digestion $(\mathrm{AD})$ of organic matter $(\mathrm{OM})$. $\mathrm{AD}$ is a biochemical process whereby $\mathrm{OM}$ is degraded under anaerobic conditions by microbial consortia (Fitzgerald, 2013; Gould, 2015; Hagos et al., 2017; Mulat and Horn, 2018). It is an eco-friendly process and one of the most efficient methods for conversion of biomass to methane $\left(\mathrm{CH}_{4}\right)$ (Horváth et al., 2016).

OMs vary in their potential to produce biogas by AD (Gould, 2015; Strong et al., 2016). Parameters used to estimate the potential of OM to produce biogas include anaerobic biogasification potential (ABP) and biochemical methane potential (BMP). These parameters allow direct evaluation of biogas yield, which can be achieved by the AD process (Jingura and Kamusoko, 2017). BMP is the maximum volume of $\mathrm{CH}_{4}$, which can be produced per gram of volatile solids (VS) in a substrate (Esposito et al., 2012). BMP provides an indication of the biodegradability of a substrate and its potential to produce $\mathrm{CH}_{4}$ via $\mathrm{AD}$ (Sell et al., 2010; Påledal et al., 2013). BMP is an important indicator of the quality of feedstock for biogas production (Triolo et al., 2013). Methods that can be used to determine BMP of feedstock were reviewed by Jingura and Kamusoko (2017). In their review, Jingura and Kamusoko (2017) indicated that the BMP test is a simple, repeatable, and inexpensive method.

The BMP of feedstock is affected by several biochemical characteristics (Gould, 2015; Strong et al., 2016; Jingura and Kamusoko, 2017). These include nutrient content, VS content, chemical oxygen demand (COD), biological oxygen demand $(\mathrm{BOD})$, carbon to nitrogen ratio $(\mathrm{C} / \mathrm{N})$, and presence of inhibitory substances (Babaee and Shayegan, 2011; Kwietniewska and Tys, 2014). Amongst these characteristics, the $\mathrm{C} / \mathrm{N}$ ratio plays a critical role in regulation of the microbial population of autotrophs and heterotrophs (Sepehri and Sarrafzadeh, 2018; Sepehri and Sarrafzadeh, 2019). Differences in biochemical characteristics make it possible to categorize feedstock on the basis of their BMP. This type of characterization places feedstock on different positions on a BMP spectrum. Feedstock at the lower end of the BMP spectrum are those, which present challenges in the $\mathrm{AD}$ process, whilst those at the upper end are highly biodegradable.

Different types of OM can be used as substrates for biogas production (Weiland, 2010; Påledal et al., 2013; Gould, 2015; Achinas et al., 2017). Feedstock for biogas production include animal manure and slurry, municipal solid waste, food waste, sewage sludge, and various types of crops and their residues (Demirbas and Balat, 2009; Achinas et al., 2017; Rabii et al., 2019). Over 200 billion tons of agricultural crop residues (CR) are produced annually in the world (Horváth et al., 2016; Patinvoh et al., 2017), presenting a vast resource for biogas production. CR are largely at the lower end of the BMP spectrum because of high lignocellulose content. Lignocellulose limits degradation by anaerobic bacteria (Wang, 2014; Achinas, 2017). CR are heterogeneous in nature limiting their use as feedstock for $\mathrm{AD}$ (Horváth et al., 2016). Sahito et al. (2013) reported a BMP range of 142 to $322 \mathrm{~mL} \mathrm{CH}_{4} \mathrm{~g} \mathrm{VS}$ ${ }^{1}$ for various CR. By comparison, feedstock such as residual fats which are at the higher end of the BMP spectrum have BMP of up to $800 \mathrm{~mL} \mathrm{CH}_{4} \mathrm{~g} \mathrm{VS}^{-1}$ (Muzenda, 2014).

There are several pretreatment options that can optimize the biomethane production from CR (Ariunbaatar et al., 2014; Ge et al., 2016; Achinas et al., 2017; Wagner et al., 2018; Liu et al., 2019). These can be classified as physical, chemical, biological, and combination of these processes (Amin et al., 2017; Patinvoh et al., 2017; Kumar et al., 2018; Mustafa et al., 2018; Venturin et al., 2018; Dahunsi, 2019; Karrupiah and Azariah, 2019). Most of the pretreatment methods have limited applications due to high energy demands, need for special equipment, and emission of several adverse by-products (Liu et al., 2019). The efficacy of pretreatment technologies varies from study to study (Amin et al., 2017; Karrupiah and Azariah, 2019). This heterogeneity limits the utility of information available in literature for planning and designing the $\mathrm{AD}$ of $\mathrm{CR}$.

Few attempts have been made to compare the efficacy of pretreatment methods used on $\mathrm{CR}$ for the purpose of biogas production by $\mathrm{AD}$. There are also limited aggregated results that provide a comparative analysis on the efficacy of the pretreatment methods with reference to CR. In view of these gaps, it is prudent to conduct a comparative analysis of the efficacy of pretreatment approaches by reviewing extant literature. This will provide empirical evidence on the comparability of existing pretreatment methods. Such information is useful for planning and enhancement of $\mathrm{AD}$ plants that utilize CR. To the best of our knowledge, this is the first systematic review study that has been undertaken to compare the efficacy of pretreatment methods in enhancing biomethane production from $\mathrm{CR}$.

\section{Methodology}

\subsection{Procedure}

The standard procedure on performing a systematic literature review (Kitchenham and Charters, 2007; Okoli and Schabram, 2010; Mittal et al., 2018) was used. The search period was January 2014 to November 2018 Most recent work on enhancing biogas production was published during this period (Prasad et al., 2017; Kougias and Angelidaki, 2018). Three databases were chosen on the basis of their availability in the university library and are among the top ten online research databases. These are Science Direct, EBSCOhost and PubMed. The search was delineated to online full-text journal articles. Gray literature covering government reports, conference proceedings, graduate dissertations and unpublished papers related to biogas was excluded. The challenges of searching gray literature were pointed out by Mahood et al. (2014) and Paez (2017).

A summary of the search protocol for identification and selection of articles for inclusion in this study is shown in Figure 1. The process for inclusion of a study was in accordance with the Preferred Reporting Items for Systematic Reviews and Meta-Analyses (PRISMA) statement (Moher et al., 2009; Forbes et al., 2018). The key search terms used for extracting the relevant articles are shown in Table 1 . These were selected using the model of a concept map (Asiksoy, 2019). 'Biogas' and 'crop residues' were the major search terms. The major search terms were held as constant in order to eliminate articles not concerned with the use of CR for biogas production.

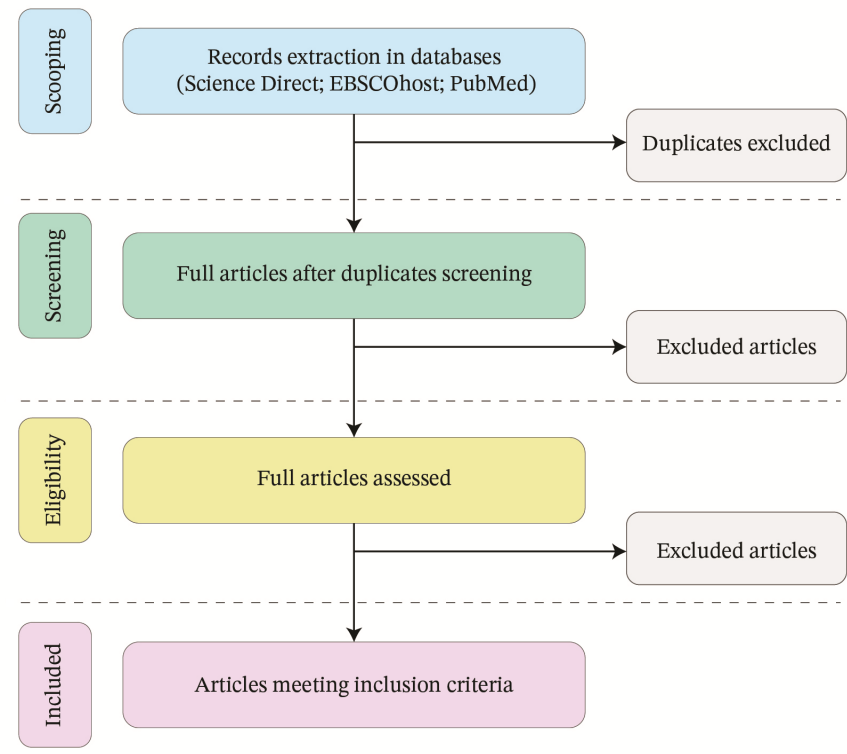

Fig. 1. Flow diagram of systematic literature review according to PRISMA (Source: Kougias and Angelidaki, 2018)

\subsection{Comparison criteria}

The main variables of interest were advantages and disadvantages of each pretreatment method in terms of techno-economic aspects. The 
Table 1.

Number of articles extracted from databases using different search terms.

\begin{tabular}{lcccc}
\hline \multirow{2}{*}{ Search terms } & \multicolumn{3}{c}{ No. of articles scooped } \\
\cline { 2 - 5 } & Science Direct & EBSCOhost & PubMed & Total \\
\hline "Pretreatment" and "crop residues" and "biogas" & 384 & 214 & 6 & 604 \\
"Chemical pretreatment" and "crop residues" and "biogas" & 365 & 651 & 1 & 1017 \\
"Biological pretreatment" and "crop residues" and " biogas" & 309 & 521 & 2 & 832 \\
"Physical pretreatment" and "crop residues" and " biogas" & 220 & 493 & 1 & 714 \\
\hline
\end{tabular}

techno-economic aspects used were: rate of hydrolysis, energy use, effectiveness, cost input, and formation of toxic compounds. These were adapted from Wagner et al. (2018) and Venturin et al. (2018). Wagner et al. (2018) considered factors such as low capital and energy use, applicability to a range of feedstock, high product yields, and low waste management. Venturin et al. (2018) considered avoidance of inhibition of AD steps, high degree of simplicity, and effectiveness as some of the characteristics of an ideal pretreatment method.

\section{Results and discussion}

\subsection{Identification and selection of articles for inclusion}

A total of 3167 full text articles were screened for relevance to the study as shown in Figure 2. Disaggregation of the number of scooped articles by search terms is shown in Table 1 . It is clearly shown that the majority of the publications $(\mathrm{n}=1017)$ were extracted by using the search terms, "chemical pretreatment" and "crop residues" and "biogas".

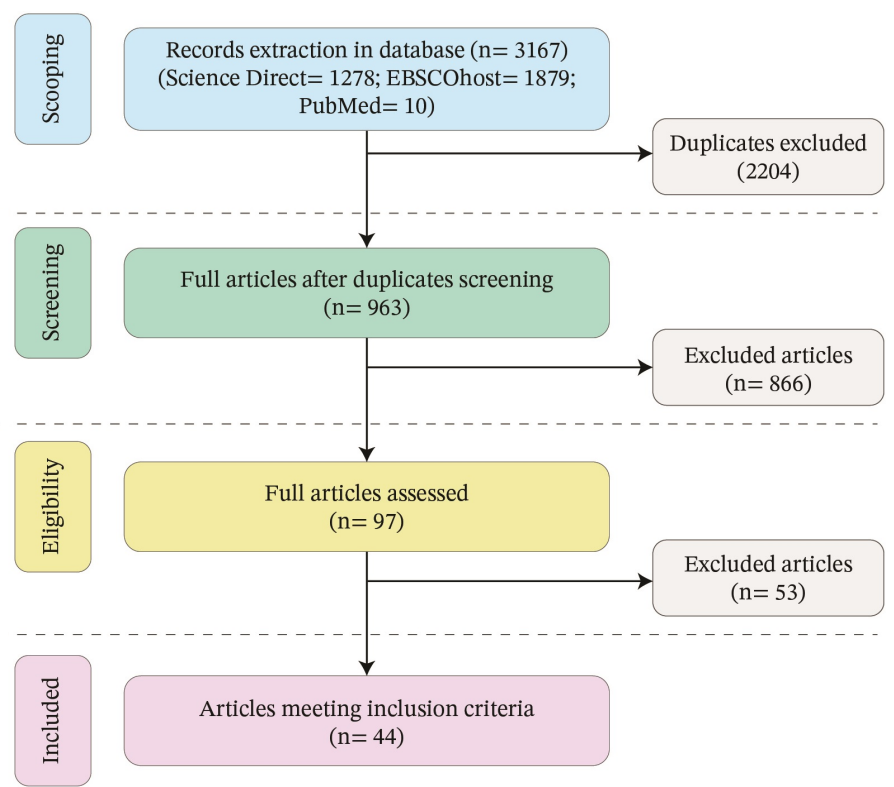

Fig. 2. Summary of identification and selection of articles for the study inclusion process.

Forty-four full text articles met the inclusion criteria. Thirty-six of the articles were research papers and eight were narrative reviews. The trend in the number of publications on pretreatment of CR for biogas production from 2014 to 2018 is shown in Figure 3. The number of publications regarding pretreatment of CR for biogas production rose between 2014 and 2017. This points to sustained research effort on the subject. This can be ascribed to the

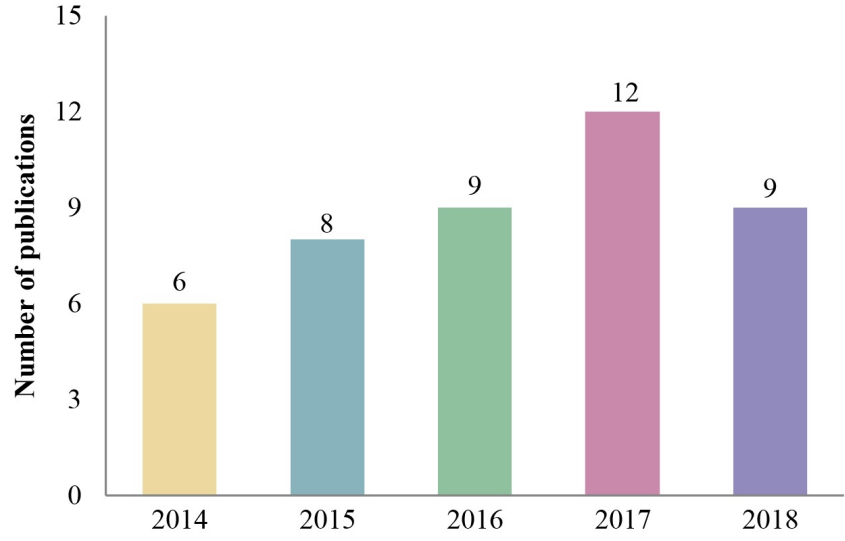

Fig. 3. Number of publications in which "pretreatment of crop residues for biogas production" appeared, based on search results by Science Direct, EBSCOhost, and PubMed.

fact that pretreatment of feedstock is a focal technology in biogas production (Kigozi et al. 2014; Horváth et al. 2016; Achinas et al. 2017). Comparably, Kougias and Angelidaki (2018) reported an increase in the number of articles retrieved from Scopus and Web of Science databases based on the keyword "biogas" between 1977 and 2017. Carrere et al (2016) also reported a similar phenomenon from 2009 to 2014 based on search terms "anaerobic digestion" and "pretreatment" in the Web of Science database. Ge et al. (2016) reported an increase in the number of articles in which the phrase "solid state anaerobic digestion" appeared in the Google Scholar database from 2005 to 2015. They noted a predominant and steady increase in the period 2010 and 2015. This indicates the increasing focus on pretreatment technology.

\subsection{Characteristics of selected articles}

The number of selected articles and the authors are shown in Table 2. The articles are organized according to the four pretreatment methods. Various pretreatment techniques are used to depolymerize CR into simple components. These are shown in Figure 4. The key pretreatment methods are chemical, physical, biological, and a combination of these processes (Montgomery and Bochmann, 2014; Yuan et al., 2014; Kumar et al., 2018).

Most of the selected articles (21) focused on chemical pretreatment methods, with the alkali technique being dominant. The dominance of the alkali technique arises from its efficacy (Kumar et al., 2018). Alkali pretreatment has been reported to have high efficiency and ability to improve the degradation of complex compounds (Amin et al., 2017). Physical and biological methods follow with 20 and 15 articles, respectively. However, fewer articles (11) focused on combined pretreatment methods. The main limitation of combined processes is their complexity (Montgomery and Bochmann, 2014). 
Table 2.

Characteristics of articles meeting inclusion criteria for comparison of pretreatment methods for crop residues

Pretreatment method No. of articles Reference

Pei et al. (2014); Sahito and Mahar (2014); Song et al. (2014); Wikandari et al. (2014); Yuan et al. (2014); Li et al. (2015); Sträuber et al. (2015); Ge et al. (2016); Constant et al. (2016); Talha et al.

Chemical (2016); Yao and Chen (2016); Amin et al. (2017); Chen et al. (2017); Gumisiriza et al. (2017); Ismail et al (2017); Kumar and Sharma (2017); Den et al. (2018); Nair et al. (2018); Perendeci et al. (2018); Thomas et al. (2018); Zhang et al. (2018)

$\begin{array}{ll} & \text { Kudanga and Le Roes-Hill (2014); Singh et al. } \\ & \text { (2014); Ge et al. (2016); Li et al. (2016); } \\ & \text { Mulakhudair et al. (2016); Thomsen et al. (2016); } \\ & \text { Amin et al. (2017); Gumisiriza et al. (2017); } \\ & \text { Kumar and Sharma (2017); Oszust et al. (2017); } \\ & \text { Rouches et al. (2017); Speda et al. (2017); } \\ \text { Zieminski and Kowalska-Wentel (2017); Byrne et } & \text { Ziemal } 15 \quad \text { al. (2018); Wagner et al. (2018) }\end{array}$

Sahito and Mahar (2014); Yuan et al. (2014); Chandra et al. (2015); Dumas et al. (2015); Luo et al. (2015); Xi et al. (2015); Wu et al. (2015); Baeta et al. (2016); Ge et al. (2016); Eskicioglu et

Physical al. (2017); Gaworski et al. (2017); Kostas et al. (2017); Li et al. (2016); Mulakhudair et al. (2016); Amin et al. (2017); Gumisiriza et al. (2017); Kumar and Sharma (2017); Zieminski and Kowalska-Wentel (2017); Paul et al. (2018); Sadhukhan et al. (2018)

Ge et al. (2016); Siddhu et al. (2016); Amin et al. (2017); Gaworski et al. (2017); Gumisiriza et al. (2017); Kumar and Sharma (2017); Zieminski Combined processes $11 \quad$ and Kowalska-Wentel (2017); Byrne et al. (2018); Kim et al. (2018); Paul et al. (2018); Zhang et al. (2018)

\subsection{Comparison of pretreatment methods}

\subsubsection{Rate of hydrolysis}

Table 3 provides information on the pretreatment methods with reference to rate of hydrolysis. According to information in Table 3, physical methods appear to be the fastest amongst the pretreatment methods. This is more so for microwave (MW) pretreatment (Wu et al., 2015; Kumar and Sharma, 2017). This is in agreement with Yuan et al (2014) who posited that short duration time is an advantage of mechanical pretreatment. Conversely, Gumisiriza et al. (2017) reported that irradiation processes are slow.

Two studies (Yuan et al., 2014; Li et al., 2015) reported that chemical pretreatment is a fast process, and three studies reported that it is a slow process (Amin et al., 2017; Gumisiriza et al., 2017; Kumar and Sharma 2017). This can be explained in terms of variation in treatment conditions. For example, retention time of chemical pretreatment is affected by reaction temperature (Sambusiti, 2013; Theuretzbacher et al., 2015). Data on combined methods is rather limited. However, combined processes were reported to be fast methods (Kumar and Sharma, 2017; Kim et al., 2018).

As shown in Table 3, studies considered in this review cited the major drawback of biological pretreatment as being a slow process (Kudanga and Le Roes-Hill, 2014; Singh et al., 2014; Mulakhudair et al., 2016; Amin et al., 2017; Gumisiriza et al., 2017; Kumar and Sharma, 2017; Den et al., 2018; Wagner et al., 2018). Generally, the required residence time is 10 $14 \mathrm{~d}$ (Amin et al., 2017). In order to enhance the rate of hydrolysis, it is recommended to optimize parameters such as nature and composition of biomass, type of microorganism involved, incubation temperature, $\mathrm{pH}$ incubation time, inoculum concentration, moisture content, and aeration rate (Sindhu et al., 2016).

\subsubsection{Energy use}

Seven studies indicated the main advantage of biological pretreatment as low energy consumption method (Table 4). Biological pretreatment enables savings on chemicals and energy (Gumisiriza et al., 2017; Kumar and Sharma, 2017; Zieminski and Kowalska-Wentel, 2017; Den et al. 2018; Wagner et al., 2018). Singh et al. (2014) pointed out that fungal

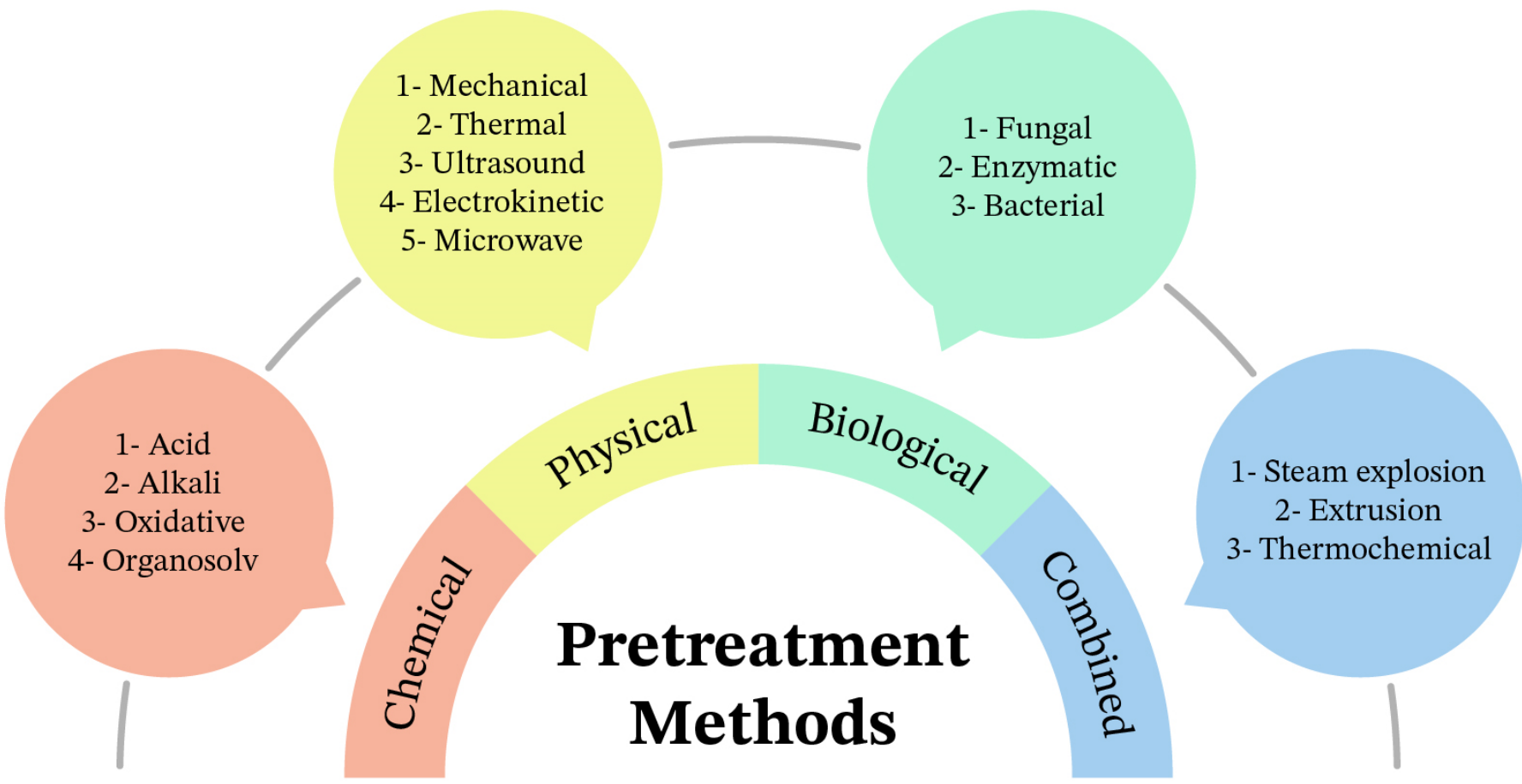

Fig. 4. Summary of pretreatment methods (Source: Montgomery and Bochmann, 2014). 
Table 3.

Comparison of pretreatment methods in terms of rate of hydrolysis.
Table 4.

Comparison of pretreatment methods in terms of energy use.
Pretreatment method Observations

\section{Reference}

$$
\begin{aligned}
& \text { Chemical pretreatments } \\
& \text { are fast }
\end{aligned}
$$

Chemical

$\begin{array}{lll}\begin{array}{l}\text { Chemical pretreatments } \\ \text { are slow }\end{array} & \begin{array}{l}\text { Amin et al. (2017); Gumisiriza et al. (2017); } \\ \text { Kumar and Sharma (2017) }\end{array} \\ & \begin{array}{l}\text { Kudanga and Le Roes-Hill (2014); Singh et } \\ \text { Biological pretreatment }\end{array} & \begin{array}{l}\text { al. (2014); Mulakhudair et al. (2016); Amin e } \\ \text { al. (2017); Gumisiriza et al. (2017); Kumar } \\ \text { and Sharma (2017); Den et al. (2018); } \\ \text { Biological }\end{array} \\ & \text { Wagner et al. (2018) }\end{array}$

Physical pretreatments Yuan et al. (2014); Wu et al. (2015); Kumar are fast and Sharma (2017)

Physical

$$
\begin{aligned}
& \text { Physical processes are Gumisiriza et al. (2017) } \\
& \text { slow }
\end{aligned}
$$

Combined processes

Combined processes are fast

pretreatment of biomass offers many advantages including low energy needs and mild reaction conditions, compared to abiotic pretreatments. Amin et al. (2017) reported that microaerobic pretreatment can be considered to be a pretreatment option for $\mathrm{AD}$ of corn straw due to low energy requirements and limited supply of oxygen. As an example, Hua et al. (2016) reported increased biogas yield from biomass pretreated by microbial consortium and ascribed this to minimal energy needs.

Physical pretreatment was reported as a high-energy consumption process (Table 4). Physical processes are very energy intensive given high temperatures and pressures involved (Mulakhudair et al., 2016; Gumisiriza et al., 2017; Speda et al., 2017; Wagner et al., 2018). For example, milling, extrusion, and crushing used for particle size reduction of straw to make it more accessible to microbial attack have high energy demands (Luo et al., 2015). Kostas et al. (2017) reported MW pretreatment to have a challenge of high energy demand. It was reported in three studies (Yuan et al., 2014; Chandra et al., 2015; Kumar and Sharma, 2017) that size reduction by mechanical comminution of lignocelluloses requires a considerable amount of energy. For instance, material such as corn stover and switch grass consumes energy worth of 11.0 and $27.6 \mathrm{kWh} /$ metric ton, respectively (Baruah et al., 2018). This is equivalent to a third of the total electricity required for the whole biogas production process (Zheng et al., 2014). For this reason, physical pretreatment is considered to be economically unviable for large scale application (Zheng et al., 2014). On the other hand, Wu et al. (2015), Kostas et al. (2017), and Kumar and Sharma (2017) reported that physical pretreatment with respect to MW pretreatment are energy efficient.

Generally, chemical methods are considered as high energy-consuming processes. This was reported in five studies (Wikandari et al., 2015; Gumisiriza et al., 2017; Rouches at al., 2017; Speda et al., 2017; Wagner et al., 2018) as shown in Table 4. Three studies (Table 4) show that combined processes are high energy-consuming methods (Gumisiriza et al., 2017; Speda et al., 2017; Perendeci et al., 2018). High temperatures and limited heat recovery during steam explosion (SE) pretreatment may lead to high energy use and reduced methane yield (Gumisiriza et al., 2017). Extrusion pretreatment also consumes high energy of about 10 to $15 \mathrm{~kW}$ of power to pretreat a tone of substrate (Montgomery and Bochmann, 2014). In contrast, three studies reported combined processes to be low energy-consuming. This observation was sustained by Kumar and Sharma (2017), Zhang et al. (2018), and Kim et al. (2019). It can be postulated that this variation in results is due to the complexity of combined methods and further research is needed.

\begin{tabular}{lll}
\hline Pretreatment method & Observations & Reference \\
\hline & $\begin{array}{ll}\text { - Chemical pretreatment } \\
\text { has low energy needs }\end{array}$ & $\begin{array}{l}\text { Sahito and Mahar (2014); Ismail et } \\
\text { al. (2017) }\end{array}$
\end{tabular}

Chemical

Wikandari et al. (2015); Gumisiriza - Chemical methods are et al. (2017); Rouches et al. (2017); energy intensive Speda et al. (2017); Wagner et al, (2018)

$\begin{array}{lll} & \\ & \begin{array}{l}\text { Singh et al. (2014); Amin et al. } \\ \text { Biological pretreatment } \\ \text { is a low energy demand } \\ \text { process }\end{array} & \begin{array}{l}\text { (2017); Gumisiriza et al. (2017); } \\ \text { Kiological }\end{array} \\ & \begin{array}{l}\text { Zieminski and Kowalska-Wentel } \\ \text { (2017); Den et al. (2018); Wagner } \\ \end{array} & \text { et al. (2018) }\end{array}$

$$
\begin{array}{ll}
\text { - Physical pretreatment } & \text { Wu et al. (2015); Kostas et al. } \\
\text { saves energy } & \text { (2017); Kumar and Sharma (2017) }
\end{array}
$$

Physical

Yuan et al. (2014); Chandra et al. (2015); Luo et al. (2015);

- Physical methods are Mulakhudair et al. (2016); very energy intensive Gumisiriza et al. (2017); Kostas et al. (2017); Kumar and Sharma (2017); Speda et al. (2017); Wagner et al. (2018)

\begin{tabular}{lll} 
Combined processes & $\begin{array}{l}- \text { Combined methods } \\
\text { require low energy }\end{array}$ & $\begin{array}{l}\text { Kumar and Sharma (2017); Kim et } \\
\text { al. (2018); Zhang et al. (2018) }\end{array}$ \\
& $\begin{array}{ll}- \text { Combined processes } \\
\text { consume high energy }\end{array}$ & $\begin{array}{l}\text { Gumisiriza et al. (2017); Speda et } \\
\text { al. (2017); Perendeci et al. (2018) }\end{array}$ \\
\hline
\end{tabular}

\subsubsection{Effectiveness}

Information in Table $\mathbf{5}$ suggests that chemical pretreatment is the most effective method. Song et al. (2014), Sträuber et al. (2015), Jiang et al (2016), Amin et al. (2017), Ismail et al. (2017), Kumar and Sharma (2017), and Rouches et al. (2017) reported that chemical pretreatments are effective for enhancing biodegradation of complex compounds such as agricultural residues and herbaceous crops. For example, Perendeci et al. (2018) observed $78 \%$ enhanced BMP from alkaline $\mathrm{H}_{2} \mathrm{O}_{2}$ pretreatment of greenhouse crop waste. Ammonia pretreatment of wheat straw effectively increased total methane yield by $17.5 \%$ (Li et al., 2015). Thomas et al. (2018) obtained 32\% more BMP from lime pre-treated Mischanthus $x$ giganteus than non-treated. Den et al. (2018) reported that acid- and alkalipretreated oil palm empty fruit bunches increased methane yield by $40 \%$ and $100 \%$, respectively.

Data in Table $\mathbf{5}$ also show that combined processes are effective methods (Amin et al., 2017; Kumar and Sharma, 2017; Kim et al., 2018 ; Perendeci et al., 2018; Zhang et al., 2018). Steam explosion was found effective in pretreatment of agricultural residues (Amin et al., 2017; Kumar and Sharma, 2017). As an example, Zhang et al. (2018) reported improved cumulative methane yield of $226.6 \%$ and $216.4 \%$ at $1.2 \mathrm{MPa}$ for $15 \mathrm{~min}$ and $1.5 \mathrm{MPa}$ for $5 \mathrm{~min}$, respectively, from steam-exploded crop straw.

As shown in Table 5, biological pretreatment is not as effective as the other methods. None of biological methods is efficient as standalone pretreatment method (Thomsen et al., 2016). For instance, no significant difference in methane yields between enzymatically-pretreated banana 
stems and non-treated stems was observed by Li et al. (2016). Paul et al. (2018) reported that fungal pretreatment of agricultural biomass did not improve methane production. However, pretreatment of rice straw with fungal strains such as Pleurotus ostreatus and Trichoderma reesei increased methane yield by $120 \%$ (Wagner et al., 2018). This variation in results is expected as biological pretreatment is still under development.

Physical pretreatment appears to be generally effective as shown in Table 5. For example, hot water pretreatment increased methane yield from rice straw by $222 \%$ (Ge et al., 2016) and MW method increased methane yield by $28 \%$ (Wu et al., 2015). Baeta et al. (2016) reported that autohydrolysis is a highly effective process. As reviewed by Den et al. (2018), MW pretreatment at 200 or $300^{\circ} \mathrm{C}$ cannot increase biogas production. Furthermore, an inverse relationship between temperature increase and biogas production was noted during MW pretreatment (Den et al., 2018). This is because high temperatures can lead to production of heat-induced inhibitors such as phenolics and furfural. As a result, MW pretreatment has been used in combination with chemical pretreatment at fairly low temperatures (Den et al., 2018).

Table 5.

Comparison of pretreatment methods in terms of effectiveness.

\begin{tabular}{|c|c|c|}
\hline Pretreatment method & Observations & Reference \\
\hline Chemical & $\begin{array}{l}\text { Chemical pretreatment } \\
\text { is an effective method }\end{array}$ & $\begin{array}{l}\text { Song et al. (2014); Li et al. (2015); } \\
\text { Sträuber et al. (2015); Jiang et al. } \\
\text { (2016); Talha et al. (2016); Amin et al. } \\
\text { (2017); Ismail et al. (2017); Kumar and } \\
\text { Sharma (2017); Rouches et al. (2017); } \\
\text { Den et al. (2018); Perendeci et al. (2018); } \\
\text { Thomas et al. (2018) }\end{array}$ \\
\hline \multirow[b]{2}{*}{ Biological } & $\begin{array}{l}\text { - Biological } \\
\text { pretreatment is an } \\
\text { effective process }\end{array}$ & Wagner et al. (2018) \\
\hline & $\begin{array}{l}\text { - Biological } \\
\text { pretreatment is not an } \\
\text { effective process }\end{array}$ & $\begin{array}{l}\text { Li et al. (2016); Thomsen et al. (2016); } \\
\text { Paul et al. (2018) }\end{array}$ \\
\hline \multirow[b]{2}{*}{ Physical } & $\begin{array}{l}\text { - Physical pretreatment } \\
\text { is an effective method }\end{array}$ & $\begin{array}{l}\text { Wu et al. (2015); Baeta et al. (2016); Ge } \\
\text { et al. (2016) }\end{array}$ \\
\hline & $\begin{array}{l}\text { - Physical pretreatment } \\
\text { is not an effective } \\
\text { process }\end{array}$ & Den et al. (2018) \\
\hline Combined processes & $\begin{array}{l}\text { Combined pretreatment } \\
\text { is an effective method }\end{array}$ & $\begin{array}{l}\text { Amin et al. (2017); Kumar and Sharma } \\
\text { (2017); Kim et al. (2018); Perendeci et } \\
\text { al. (2018); Zhang et al. (2018) }\end{array}$ \\
\hline
\end{tabular}

\subsubsection{Cost}

Table 6 compares the different pretreatments in terms of cost of operation. Despite reported to be less effective, biological pretreatment is considered to be variable in cost-effectiveness. Biological pretreatments were reported to be inexpensive (Mulakhudair et al., 2016; Gumisiriza et al., 2017; Den et al., 2018; Wagner et al., 2018). For instance, Rouches et al. (2017) stated that fungal pretreatments are cost-effective. This is because use of fungi helps to reduce the number of pretreatment steps and costs by avoiding enzyme recovery steps (Carrerre et al., 2016). Kudanga and Le Roes-Hill (2014) reported that enzyme pretreatments have low utility costs of enzymes due to the use of mild conditions. As reported by Amin et al. (2017), microaerobic pretreatment (MP) is more economically and environmentally friendly than other pretreatment methods. During MP, microorganisms are partially exposed to $\mathrm{O}_{2}$ or air under moderate operating conditions such as temperature and pressure. MP has also minimal enzyme and energy requirements (Mustafa et al., 2018). The process is designed to promote the hydrolysis stage through stimulation of cell growth and activity (Wagner et al., 2018). MP is likely to be one of the most promising

Table 6.

Comparison of pretreatment methods in terms of cost.

\begin{tabular}{lll}
\hline Pretreatment method & Observations & Reference \\
\hline & - Chemical & \\
pretreatments are & Song et al. (2014); Amin et al. (2017); \\
relatively & Gumisiriza et al. (2017); Ismail et al. \\
inexpensive & (2017), Kumar and Sharma (2017)
\end{tabular}

Chemica

Sträuber et al. (2015); Wikaandari et a (2015); Amin et al. (2017); Kumar and Chemical methods Sharma (2017); Rouches et al. (2017); Speda et al. (2017); Den et al. (2018); Sadhukhan et al. (2018); Wagner et al. (2018)

$\begin{array}{lll} & \begin{array}{l}\text { Kudanga and Le Roes-Hill (2014); } \\ \text { - Biological } \\ \text { pretreatments are } \\ \text { cost-effective }\end{array} & \begin{array}{l}\text { Mulakhudair et al. (2016); Amin et al. } \\ \text { (2017); Gumisiriza et al. (2017); } \\ \text { Rouches et al. (2017); Den et al. } \\ \text { (2018); Wagner et al. (2018) }\end{array} \\ \text { Biological } & \begin{array}{l}\text { - Biological } \\ \text { pretreatments are } \\ \text { costly }\end{array} & \begin{array}{l}\text { Kudanga and Roes-Hill (2014); Sahito } \\ \text { and Mahar (2014); Li et al. (2016); } \\ \text { Mulakhudair et al. (2016) }\end{array} \\ & \begin{array}{l}\text { - Physical } \\ \text { pretreatments are } \\ \text { inexpensive }\end{array} & \text { Kostas et al. (2017) }\end{array}$

Physical

$$
\begin{aligned}
& \text { - Physical } \\
& \text { pretreatment } \\
& \text { methods are }
\end{aligned}
$$
expensive

\begin{tabular}{lll} 
& $\begin{array}{l}\text { - Combined } \\
\text { processes are cost- } \\
\text { effective }\end{array}$ & $\begin{array}{l}\text { Gumisiriza et al. (2017); Kumar and } \\
\text { Sharma (2017); Zhang et al. (2018) }\end{array}$ \\
Combined processes & $\begin{array}{l}\text { - Combined } \\
\text { processes are } \\
\text { expensive }\end{array}$ & Speda et al. (2017) \\
\hline
\end{tabular}

technologies in the foreseeable future. Contrarily, biological pretreatment was reported to be costly with respect to production costs due to the use of commercial enzymes (Kudanga and Le Roes-Hill, 2014; Sahito and Mahar, 2014; Li et al., 2016; Mulakhudair et al., 2016).

It is noted that, despite variations shown in Table 6 , chemical and physical pretreatments appear to be predominantly expensive. Selected results show that chemical or physical pretreatments are expensive and not economically viable for biogas production from CR. Chemica pretreatments were reported to be expensive due to high costs of disposal of digestion residues (Wagner et al., 2018), use of extraneous agent which incurs higher cost of chemicals and downstream processing (Sträuber et al. 2015; Amin et al., 2017; Kumar and Sharma, 2017; Den et al., 2018; Sadhukhan et al., 2018), the need for expensive auxiliary equipment (Wikaandari et al., 2015; Speda et al., 2017), and high operational and maintenance costs (Rouches et al., 2017). Other studies reported chemical methods with respect to alkali pretreatment to be inexpensive (Song et al. 2014; Amin et al., 2017; Gumisiriza et al., 2017; Ismail et al., 2017; Kumar and Sharma, 2017). The benefit of $\mathrm{Ca}(\mathrm{OH})_{2}$ pretreatment is the low disposal costs as $\mathrm{Ca}$ can be easily recovered from the hydrolyzate (Amin et al. 2017). Based on pretreatment of corn straw, $\mathrm{Ca}(\mathrm{OH})_{2}$ could be a better option than $\mathrm{NaOH}$ although their pretreatment costs were not highly variable (Song et al., 2014). Alkali pretreatment was favored over other pretreatments due to low operational costs (Ismail et al., 2017). The low cost of lime and ease of recovery from the waste make it a better pretreatment technology than other alkalis (Kumar et al., 2017). 
Table 7.

Comparison of pretreatment methods in terms of formation of toxic compounds.

\begin{tabular}{lll}
\hline Pretreatment method & Observations & Reference \\
\hline & $\begin{array}{ll}\text { - Chemical pretreatment } \\
\text { avoids formation of toxic } \\
\text { inhibitory compounds }\end{array}$ & $\begin{array}{l}\text { Sahito and Mahar (2014); Gumisiriza } \\
\text { et. (2018); Den et al. (2018); Paul et }\end{array}$
\end{tabular}

Chemical

$$
\begin{aligned}
& \text { - Chemical pretreatment } \\
& \text { produces toxic inhibitory } \\
& \text { compounds }
\end{aligned}
$$

$\begin{array}{lll}\text { Biological } & \begin{array}{l}\text { Biological pretreatment } \\ \text { reduces formation of } \\ \text { inhibitory substances }\end{array} & \begin{array}{l}\text { Singh et al. (2014); Amin et al. } \\ \text { (2017); Wagner et al. (2018) }\end{array} \\ & \begin{array}{l}\text { - Physical pretreatment } \\ \text { avoids formation of toxic } \\ \text { inhibitory compounds }\end{array} & \begin{array}{l}\text { Baeta et al. (2016); Kumar and } \\ \text { Sharma (2017) }\end{array} \\ \text { Physical } & \begin{array}{l}\text { - Physical pretreatment } \\ \text { produces toxic inhibitory } \\ \text { compounds }\end{array} & \begin{array}{l}\text { Ku et al. (2015); Zieminski and } \\ \text { Kowalsk-Wentel (2017); Speda et al. } \\ \text { al. (2018) }\end{array} \\ & \begin{array}{l}\text { Combined processes } \\ \text { generates toxic inhibitory } \\ \text { compounds }\end{array} & \begin{array}{l}\text { Amin et al. (2017); Perendeci et } \\ \text { (2017); Gumisiriza et al. (2017); } \\ \text { Kumar and Sharma (2017); Speda et } \\ \text { al. (2017); Zhang et al. (2018) }\end{array} \\ \text { Combined processes }\end{array}$

Kostas et al. (2017) reported that MW heating proffers opportunities to reduce the capital cost of processing. However, most studies reported that physical pretreatment is an expensive process. This is mainly due to higher energy and capital cost (Sadhukhan et al., 2018). Milling, grinding, ultrasonic, and irradiation processes have high energy and equipment maintenance costs (Song et al., 2014; Amin et al., 2017; Gumisiriza et al., 2017; Ismail et al., 2017; Kumar and Sharma, 2017). Combined methods are affected by costs associated with the other three methods. SE pretreatment requires expensive auxiliary equipment (Speda et al., 2017), although it was regarded as inexpensive (Gumisiriza et al., 2017; Kumar and Sharma, 2017; Zhang et al., 2018).

\subsubsection{Formation of toxic compounds}

Table 7 provides information regarding formation of toxic inhibitory compounds. Biological pretreatment avoids formation of inhibitors of biogas production (Singh et al., 2014; Amin et al., 2017; Wagner et al., 2018). This is a positive attribute of biological pretreatment. While some chemical pretreatment methods do not produce inhibitory compounds (Sahito and Mahar, 2014; Den et al., 2018; Gumisiriza et al., 2017; Paul et al., 2018), 11 studies in Table 7 reported that chemical pretreatment causes formation of toxic compounds. As such, formation of inhibitory compounds is one of the disadvantages of chemical pretreatment. Production of inhibitors of methanogenic metabolism and growth can be ascribed to elevated levels of alkalinity and $\mathrm{pH}$. The ultimate result is earlier process failure during biomethane production. The optimum $\mathrm{pH}$ range for methanogenic activity is 6.5 to 8.2 . Alkaline addition provides buffering capacity and prevents inhibition during $\mathrm{AD}$ (Chen et al., 2015).

As shown in Table 7, physical processes generally lead to formation of inhibitory compounds. For instance, thermal pretreatment at temperatures above $160^{\circ} \mathrm{C}$ may lead to partial degradation of polysaccharides and lignin to phenolic and heterocyclic compounds (Zieminski and Kowalska-Wentel, 2017). However, some of the studies (Baeta et al., 2016; Kumar and Sharma, 2017) show that autohydrolysis and mill pretreatment do not generate toxic compounds. Seven studies in Table 7 show that combined processes generate inhibitory compounds, especially SE pretreatment. Zheng et al. (2014) reported that the efficacy of SE and extrusion may be affected by production of fermentation inhibitory substances such as furfural and hydroxymethylfurfural (HMF) due to sugar and lignin degradation. This can explain the $\mathrm{CH}_{4}$ yield loss during high temperature SE pretreatment of late harvested hay observed by Bauer et al. (2014).

\subsubsection{Aggregated results}

Table 8 provides aggregated results of the five parameters for all the pretreatment methods. Putting together, biological methods have more techno-economic advantages across the five parameters compared to other methods. The advantages of biological pretreatments are tagged with low energy use, low cost, and ability to avoid formation of by-products that are toxic to methanogens. However, there is need to improve on the efficacy of biological pretreatment. Focus area should be enhancement of the rate of hydrolysis. Despite high effectiveness, the main limitations of chemical and physical methods are high energy use and cost, as shown in Table 8 .

\section{Conclusions}

It is evident from this study that pretreatment methods used for CR are variable in their effects. As such, the multi-factor evaluation conducted in this study provides information that can assist selection of methods to use. Rate of hydrolysis, energy use, effectiveness, cost, and formation of toxic compounds are critical parameters that inform selection of a pretreatment method. Physical and chemical pretreatment methods have been utilized to some extent at industrial scale for delignification of $\mathrm{CR}$ to enhance biomethane production. However, these methods are energy intensive, expensive, not environmentally safe, and have the ability to generate toxic compounds including carboxylic acids, furans, and phenolic compounds which may be inhibit methanogenic activity. In comparison with other methods, biological pretreatment offers more techno-economic advantages. Biological pretreatment is regarded as inexpensive and low energy need process that can minimize formation of inhibitory compounds. Thus,

Table 8.

Aggregated comparison of the pretreatment methods.

\begin{tabular}{lccccc}
\hline Pretreatment method & Rate of hydrolysis & Energy use & Effectiveness & Cost & $\begin{array}{c}\text { Generation of toxic } \\
\text { compounds }\end{array}$ \\
\hline Chemical & Fast & High & Very effective & Very expensive & Yes \\
Biological & Slow & Very low & Less effective & Cost-effective & No \\
Physical & Very fast & Very high & Moderately effective & Very expensive & Yes \\
Combined processes & Fast & Moderate & Effective & Cost-effective & Yes \\
\hline
\end{tabular}


biological pretreatment is one of the most promising technologies for enhancing biomethane production of CR. Moreover, rigorous research is still needed for the development of novel microorganisms and more efficient pretreatment options for $\mathrm{CR}$ yielding potential results.

\section{Acknowledgements}

This work was carried out with the support of Chinhoyi University of Technology through Staff Development Fellowship.

\section{References}

[1] Achinas, S., Achinas, V., Euverink, G.J.W., 2017. A technological overview of biogas production from biowaste. Engineering. 3(3), 299-307.

[2] Alhassan, K.A., Abdullahi, B.T., Shah, M.M., 2019. A review on biogas production as the alternative source of fuel. J. Appl. Adv. Res. 4(2), 6165.

[3] Amin, R.F., Khalid, H., Zhang, H., Rahman, S., Zhang, R., Liu, G., Chen, C., 2017. Pretreatment methods of lignocellulosic biomass for anaerobic digestion. AMB Express.

$7(1), 72$.

[4] Ariunbaatar, J., Panico, A., Esposito, G., Pirozzi, F., Lens, P.N., 2014. Pretreatment methods to enhance anaerobic digestion of organic solid waste. Appl. Energy. 123, 143-156.

[5] Asiksoy, G., 2019. Computer-based concept mapping as a method for enhancing the effectiveness of concept learning in technology-enhanced learning. Sustainability. 11(4), 1005

[6] Babaee, A., Shayegan, J., 2011. Effect of organic loading rates (OLR) on production of methane from anaerobic digestion of vegetables waste in proceedings of the world renewable energy congress. Linköping, Sweden.

[7] Baeta, B.E.L., Lima, D.R.S., Adarme, O.F.H., Gurgel, L.V.A., Aguino, S.F., 2016. Optimization of sugarcane bagasse autohydrolysis for methane production from lignocellulosic hydrolyzates in a biorefinery concept. Bioresour. Technol. 200, 137-146.

[8] Baruah, J., Nath, B.K., Sharma, R., Kumar, S., Deka, R.C., Baruah, D.C., Kalita, E., 2018.

Recent trends in the pretreatment of lignocellulosic biomass for valueadded products. Front Energy Res. 6, 141

[9] Bauer, A., Lizasoain, J., Theuretzbacher, F., Agger, J.W., Rincon, M., Menardo, S., Saylor, M.K., Enguídanos, R., Nielsen, P.J., Potthast, A., Zweckmair, T., 2014. Steam explosion pretreatment for enhancing biogas production of late harvested hay. Bioresour. Technol. 166, 403-410.

[10] Byrne, E., Kovacs, K., Van Nielet, E.W., Willquist, K., Svensson, S.E., Kreuger, E., 2018. Reduced phosphorous and water in sequential dark fermentation and anaerobic digestion of wheat straw and the application of ensiled steam-pretreated lucerne as a macronutrient provider in anaerobic digestion. Biotechnol. Biofuels. 11(1), 281.

[11] Carrerre, H., Antonopoulou, G., Affes, R., Passos, F., Battimelli, A., Lyberatos, G., Ferrer, I., 2016. Review of Feedstock pretreatment strategies for improved anaerobic digestion: from lab-scale research to full-scale application. Bioresour. Technol. 199, 386-397.

[12] Chandra, R., Hakeuchi, H., Hasegawa, T., Vijay, V.K., 2015. Experimental evaluation of substrate's particle of wheat and rice straw biomass on methane production yield. Agric. Eng. Int. CIGR J. 17(2), $93-$ 104

[13] Chen, S., Jang, J., Wang, X., 2015. Effects of alkalinity sources on the stability of anaerobic digestion from food waste. Waste Manage. Res. 33(11), 1033-1040

[14] Chen, X.L., Han, Y.X., Zhang, C.M., Feng, G.Q., Zhao, M.X., Yue, R.X., Li, Y.F., Jiang, L., Zhang, L., Li, J.H., Li, S.Z., 2017. Alkaline pretreatment of banana stems for methane generation: effects of temperature and physico-chemical changes. BioResources. 12(3), 56015616.

[15] Constant, S., Barakat, A., Robitzer, M., Di Renzo, F., Dumas, C., Quignard, F., 2016. Composition, texture and methane potential of cellulosic residues from Lewis acids organosolv pulping of wheat straw. Bioresour. Technol. 216, 737-743.
[16] Dahunsi, S.O., 2019. Mechanical pretreatment of lignocelluloses for enhanced production: methane yield prediction from biomass structural components. Biresour. Technol. 280, 18-26.

[17] Demirbas, M.F., Balat, M., 2009. Progress and recent trends in biogas processing. Int. J. Green Energy. 6(2), 117-142.

[18] Den, W., Sharma, V.K., Lee, M., Nadadur, G., Varma, R.S., 2018. Lignocellulosic biomass transformations via greener oxidative pretreatment processes: access to energy and valueadded chemicals. Front. Chem. 6, 141

[19] Dumas, C., Ghizzi, G.S.G., Barakat, A., Carrere, H., Steyer, J.P. Rouau, X., 2015. Effects of grinding processes on anaerobic digestion of wheat straw. Ind. Crops Prod. 74, 450-456.

[20] Eskicioglu, C., Monlau, F., Barakat, A., Ferrer, I., Kaparaju, P. Trably, E., Carrere, H., 2017. Assessment of hydrotherma pretreatment of various lignocellulosic biomass with $\mathrm{CO}_{2}$ catalyst for enhanced methane and hydrogen production. Water Res. 120, 32-42.

[21] Esposito, G., Frunzo, L., Liotta, F., Panico, A., Pirozzi, F., 2012. Biomethane potential tests to measure the biogas production from the digestion and co-digestion of complex organic substrates. Open Environ. Eng. J. 5, 1-8.

[22] Fitzgerald, G.C., 2013. Pre-processing and treatment of municipal solid waste (MSW) prior to incineration, in: Klinghoffer, N.B. Castaldi, M.J. (Eds.), Waste to Energy Conversion Technology. Woodhead Publishing Limited, pp. 55-71

[23] Forbes, C.A., Deshpande, S., Sorio-Vilela, F., Kutikova, L., Duffy, S., Gouni-Berthold, I., Hagstrom, E., 2018. A systematic literature review comparing methods for the measurement of patient persistence and adherence. Curr. Med. Res. Opin. 34(9), 1613-1625.

[24] Gaworski, M., Jablonski, S., Pawlaczyk-Graja, I., Ziewiecki, R., Rutkowski, P., Wieczynska, A., Gancarz, R., Łukaszewicz, M., 2017. Enhancement of biogas plant production using pig manure and corn silage by adding wheat straw processed with liquid hot water and steam explosion. Biotechnol. Biofuels. 10, 259.

[25] Ge, X., Xu, F., Li, Y., 2016. Solid-state anaerobic digestion of lignocellulosic biomass: recent progress and perspectives. Bioresour. Technol. 205, 239-249.

[26] Gould, M.C., 2015. Bioenergy and anaerobic digestion, in: Dahiya, A. (Ed.), Bioenergy: Biomass to Biofuels. Elsevier, pp. 297-317.

[27] Gumisiriza, R. Hawumba, J.F., Okure, M. Hensel, O., 2017. Biomass waste-to-energy valorisation technologies: a review case for banana processing in Uganda. Biotechnol. Biofuels. 10, 11.

[28] Hagos, K., Zong, J., Li, D., Liu, C., Lu, X., 2017. Anaerobic codigestion process for biogas production: progress, challenges and perspectives. Renew. Sust. Energy Rev. 76, 1485-1496.

[29] Horváth, I.S., Tabatabaei, M., Karimi, K., Kumar, R., 2016. Recent updates on biogas production-a review. Biofuel Res. J. 10, 394-402.

[30] Hua, B., Dai, J., Liu, B., Zhang, H., Yuan, X., Wang, X., Cui, Z., 2016. Pretreatment of non-sterile, rotted silage maize straw by the microbial community $\mathrm{MC} 1$ increases biogas production. Bioresour. Technol. 216, 699-705.

[31] Ismail, S., Saharuddin, M.Q., Zahari, M.S.M., 2017. Upgraded seawater-alkaline pretreatment of lignocellulosic biomass for biomethane production. Energy Procedia. 138, 372-379.

[32] Jingura, R.M., Kamusoko, R., 2017. Methods for determination of biomethane potential of feedstocks: a review. Biofuel Res. J. 4(2), 573-586.

[33] Karrupiah, T., Azariah, V.E., 2019. Biomass pretreatment for enhancement of production. IntechOpen.

[34] Kigozi, R., Muzenda, E., Aboyade, A.O., 2014. Biogas technology, current trends, opportunities and challenges, in: $6^{\text {th }}$ International Conference on Green Technology, Renewable Energy \& Environmental Engineering. Cape Town, South Africa, pp. 27-28.

[35] Kim, D., Kim, J., Lee, C., 2018. Effect of mild-temperature thermoalkaline pretreatment on solubilization and anaerobic digestion of spent coffee grains. Energies. 11(4), 865.

[36] Kitchenham, B., Charters, S., 2007. Guidelines for performing systematic literature reviews in software engineering. EBSE Technical Report. Keele University, UK and University of Durham, UK. 
[37] Kostas, E.T., Beneroso, D., Robinson, J.P., 2017. The application of microwave heating in bioenergy: a review of the microwave pretreatment and upgrading technologies for biomass. Renew. Sust. Energy Rev. 77, $12-27$

[38] Kougias, P.G., Angelidaki, I., 2018. Biogas and its opportunities-a review. Front. Environ. Sci. Eng. 12(3), 14.

[39] Kudanga, T., Le Roes-Hill, M., 2014. Laccase applications in biofuel production: current status and future prospects. Appl. Microbiol. Biotechnol. 98(15), 6525-6542.

[40] Kumar, A.K., Sharma, S., 2017. Recent updates on different methods of pretreatment of lignocellusic feedstocks: a review. Bioresour. Bioprocess. 4(1), 7.

[41] Kumar, S., Paritosh, K., Pareek, N., Chawade, A., Vivekanand, V., 2018. De-construction of major Indian cereal crop residues through chemical pretreatment for improved biogas production: an overview. Renew. Sust. Energy Rev. 90, 160-170.

[42] Kwietniewska, E., Tys, J., 2014. Process characteristics, inhibition factors and methane yields of anaerobic digestion process, with particular focus on microalgal biomass fermentation. Renew. Sust. Energy Rev. 34, $491-$ 500

[43] Li, C., Liu, G., Nges, I.A., Deng, L., Nistor, M., Liu, J., 2016. Fresh banana pseudo-stems as a tropical lignocellulosic feedstock for methane production. Energy Sustain. Soc. 6,27.

[44] Li, X., Dang, F., Zhnag, Y., Zou, D., Yuan, H., 2015. Anaerobic digestion performance and mechanism of ammoniation pretreatment of corn stover. BioRes. 10(3), 5777-5790.

[45] Liu, T., Zhou, X., Li, Z., Wang, X., Sun, J., 2019. Effects of liquid digestate pretreatment on biogas production for anaerobic digestion of wheat straw. Bioresour. Technol. 280, 345351.

[46] Luo, T., Long, Y., Li, J., Meng, X., Mei, Z., Long, E., Dai, B., 2015. Performance of a novel downward plug-flow anaerobic digester for methane production from chopped straw. BioRes. 10(1), 943-955.

[47] Mahood, Q., Eerd, D.V., Irvin, E., 2014. Searching for grey literature for systematic reviews: challenges and benefits. Res. Synth. Methods. 5(3), 221-234.

[48] Mittal, S., Ahlgren, E.O., Shukla, P.R., 2018. Barriers to biogas dissemination in India. Energy Policy. 112, 361-370.

[49] Moher, D., Liberati, A., Tetzlaff, J et al., 2009. Preferred reporting items for systematic reviews and meta-analyses: the PRISMA statement. Br. Med. J. 339, b2535.

[50] Montgomery, L.F.R., Bochmann, G., 2014. Pretreatment of feedstock for enhanced production. Technical Brochure. IEA Bioenergy.

[51] Mulakhudair, A.R., Hanotu, J., Zimmerman, W., 2016. Exploiting microbubble-microbe synergy for biomass processing: application in lignocellulosic biomass pretreatment. Biomass Bioenergy. 93, 187-193.

[52] Mulat, D.G., Horn, S.J., 2018. Biogas production from lignin via anaerobic digestion, in: Beckham, G.T. (Ed.), Lignin Valorization: Emerging Approaches, Energy and Environment, series no. 19., Royal Society of Chemistry, pp. 391-412

[53] Mustafa, A.M., Li, H., Radwan, A.A., Sheng, K., Chen, X., 2018. Effect of hydrothermal and $\mathrm{Ca}(\mathrm{OH})_{2}$ pretreatments on anaerobic digestion of sugarcane bagasse for biogas production. Bioresour. Technol. 259, 54-60.

[54] Muzenda, E., 2014. Bio-methane generation from organic waste: a review, in: Proceedings of the World Congress on Engineering and Computer Science, vol II. San Fransisco, USA.

[55] Nair, R.B., Kabir, M.M., Lennartsson, P.R., Taherzadeh, M.J., Horvath, I.S., 2018. Integrated process for ethanol, biogas and edible filamentous fungi-based animal feed production from dilute phosphoric acidpretreated wheat straw. Appl. Biochem. Biotechnol. 184(1), 48-62.

[56] Okoli, C., Schabram, K., 2010. A guide to conducting a systematic literature review of information systems research. Sprouts: Working Papers on Information Systems. 10(26).

[57] Oszust, K., Pawlik, A., Janusz, G., Zieminski, K., Cyran, M., Siczek, A., Gryta, A., Bilińska-Wielgus, N., Frac, M., 2017. Characterization and influence of a multi-enzymatic biopreparation for biogas yield enhancement. BioRes. 12(3), 6187-6206.

[58] Paez, A., 2017. Gray literature: An important resource in systematic reviews. J. Evid. Based Med.10, 233-240.

[59] Påledal, S.N., Moestedt, J., Nordell, E., 2013. The importance of complex nutrient solution in biochemical methane potential tests to achieve more reliable results, in: Proceedings of the $13^{\text {th }}$ World Congress on Anaerobic Digestion, Santiago de Compostella.

[60] Patinvoh, R.J., Osadolor, O.A., Chandolias, K., Horvath, S. Taherzadeh, M.J., 2017. Innovative pretreatment strategies for biogas production. Bioresour. Technol. 224, 13-24

[61] Paul, S., Dutta, A., Defersha, F., 2018. Mechanical and alkaline hydrothermal treated corn residue conversion into bio-energy and biofertilizer: a resource recovery concept. Energies. 11(3), 516.

[62] Pei, P., Zhang, C., Li, J., Chang, S., Li, S., Wang, J., Zhao, M et al. 2014. Optimization of $\mathrm{NaOH}$ pretreatment for enhancement of biogas production of banana pseudo-stem fiber using response surface methodology. BioRes. 9(3), 5073-5087

[63] Perendeci, N.A., Gokgol, S., Orhon, D., 2018. Impact of alkaline $\mathrm{H}_{2} \mathrm{O}_{2}$ pretreatment on methane generation potential of greenhouse crop waste under anaerobic conditions. Molecules. 23, 1794.

[64] Prasad, S., Rathore, D., Singh, A., 2017. Recent advances in biogas production. Chem. Engin. Process Tech. 3(2), 1038

[65] Rabii, A., Aldin, S., Dahman, Y., Elbeshbishy, E., 2019. A review of anaerobic codigestion with a focus on the microbial populations and the effect of multi-stage digester configuration. Energies. 12, 1106.

[66] Rouches, E., Dignac, M., Zhou, S., Carrere, H., 2017. Pyrolysis-GC MS to assess the fungal pretreatment efficiency for wheat straw anaerobic digestion. J. Anal. Appl. Pyrolysis. 123, 409-418.

[67] Sadhukhan, J., Martinez-Hernandez, E., Murphy, R.J., Ng, D. Ks. Hassim, M.H., Ng, K.S., Kin, W.Y et al., 2018. Role of bioenergy, biorefinery and bioeconomy in sustainable development: strategic pathways for Malaysia. Renew. Sust. Energ. Rev. 81(2), 1966-1987.

[68] Sahito, A.R., Mahar, R.B., 2014. Enhancing methane production from rice straw codigested with buffalo dung by optimising effect of substrate ratio, alkaline dose and particle size. J. Anim. Plant Sci. 24(4), 1076-1084.

[69] Sahito, A.R., Mahar, R.B, Brohi, K.M., 2013. Anaerobic biodegradability and methane potential of crop residue co-digested with buffalo dung. Res. J. Eng. Technol. 32(3), 509-518.

[70] Sambusiti, C., 2013. Physical, chemical and biological pretreatment to enhance biogas production from lignocellulosic substrates. Dissertation. Politecnico Di Milano, Milan, Italy.

[71] Sell, S.T., Burns, R.T., Raman, D.R., Moody, L.B., 2010. Approaches for selecting anaerobic digestion co-substrates for a full-scale beef manure digester using biochemical methane potentials and anaerobic toxicity assays, in: Proceedings of the International Symposium on Air Quality and Manure Management for Agriculture. Dallas, Texas.

[72] Sepehri, A., Sarrafzadeh, M., 2018. Effects of nitrifiers community on fouling mitigation and nitrification efficiency in a membrane bioreactor. Chem. Eng. Process. 128,10-18.

[73] Sepehri, A., Sarrafzadeh, M., 2019. Activity of enhancement of ammonia-oxidizing bacteria and nitrite-oxidizing bacteria in activated sludge process: metabolite reduction and $\mathrm{CO}_{2}$ mitigation intensification process. Appl. Water. Sci. 9, 131.

[74] Sindhu, R., Binod, P., Pandey, A., 2016. Biological pretreatment of lignocellulosic biomass- An overview. Bioresour. Technol. 199, 76 82.

[75] Singh, S., Harms, H., Schlosser, D., 2014. Screening of ecologically diverse fungi for their potential to pretreat lignocellulosic bioenergy feedstock. Appl. Microbiol. Biotechnol. 98(7), 3355-3370.

[76] Song, Z., Yang, G., Liu, X., Yan, Z., Yuan, Y., Liao, Y., 2014 Comparison of seven chemical pretreatments of corn straw for improving methane yield by anaerobic digestion. PLoS One. 9(4), e93801.

[77] Speda, J., Johansson, M.A., Odnell, A., Karlsson, M., 2017. Enhanced bio-methane production rate and yield from lignocellulosic ensiled forage ley by in situ anaerobic digestion treatment with endogenous cellulolytic enzymes. Biotechnol. Biofuels. 10,129.

[78] Sträuber, H., Bühligen, F., Kleinsteuber, S., Nikolausz, M., Porsch, K., 2015. Improved anaerobic fermentation of wheat straw by alkaline pretreatment and addition of alkali tolerant microorganisms. Bioengineering. 2(2), 66-93

[79] Strong, P.J., Kalyuzhnaya, M., Silverman, J., Clarke, W.P., 2016. A methanotroph-based biorefinery: scenarios for generating multiple products from a single culture. Bioresour. Technol. 215, 314-323. 
[80] Talha, Z., Ding, W., Mehryar, E., Hassan, M., Bi, J., 2016. Alkaline pretreatment of sugarcane bagasse and filter mud co-digested to improve bio-methane production. BioMed. Res. Int. 8650597, 10.

[81] Theuretzbacher, F., Lizasoain, J., Lefever, C., Saylor, M.K., Enquidanos, R., Weran, N., Gronauer, A et al., 2015. Steam explosion pretreatment of wheat straw to improve methane yields: Investigation of the degradation kinetics of structural compounds during anaerobic digestion. Bioresour. Technol. 179, 299-305.

[82] Thomas, H.L., Seira, J., Escudié, R., Carrére, H., 2018. Lime pretreatment of miscanthus: impact on BMP and batch dry co-digestion with cattle manure. Molecules. 23(7), 1608.

[83] Thomsen, S.T., Londono, J.E.G., Ambye-Jensen, M., Heiske, S., Kadar, Z., Meyer, A.S., 2016. Combination of ensiling and fungal delignification as effective wheat straw pretreatment. Biotechnol. Biofuels. 9,16.

[84] Triolo, J.M., Ward, A.J., Pedersen, L., Pederson, L., Sommer, S.G., 2013. Characteristics of animal slurry as a key biomass for biogas production in Denmark, in: Matovic, M.D. (Ed.), Biomass Now - Sustainable Growth and Use. Intech, pp. 307-326.

[85] Venturin, B., Frumi, C.A., Scapini, T., Mulinari, J., Bonatto, C., Bazoti, S., Pereira, S.D et al., 2018. Effect of pretreatments on corn stalk chemical properties for biogas production purposes. Bioresour. Technol. 266, 116124.

[86] Wagner, A.O., Lackner, N., Mutschlechner, M., Prem, E.M., Markt, R., IIImer, P., 2018. Biological pretreatment strategies for second-generation lignocellulosic resources to enhance biogas production. Energies. 11, 1797.

[87] Wang, J., 2014. Decentralized biogas technology of anaerobic digestion and farm ecosystem: opportunities and challenges. Front. Energy Res.
[88] WBA: World Bioenergy Association, 2018. WBA Global Bioenergy Statistics 2018

[89] Weiland, P., 2010. Biogas production: current state and perspectives. Appl. Microbiol. Biotechnol. 85, 849-860.

[90] Wikandari, R., Nguyen, H., Millati, R., Niklasson, C., Taherzadeh, M.J., 2014. Improvement of biogas production from orange peel waste by leaching of limonene. BioMed. Res. Int. 494182, 6.

[91] Wu, C., Zhou, H., Yang, F., Zhang, Y., Gao, F., 2015. Microwave pretreatment of switchgrass leaf and stem fractions to increase methane production. BioRes. 10(3), 3922-3933.

[92] Xi, Y., Chang, Z., Ye, X., Du, J., Chen, G., Xu, Y., 2015. Enhanced methane production from anaerobic co-digestion of wheat straw and herbal-extraction processing residues. BioRes. 10(4), 7985-7997.

[93] Yao, Y., Chen, S., 2016. A novel and simple approach to the good performance of methane recovery from lignocellulosic biomass alone. Biotechnol. Biofuels. 9,115.

[94] Yuan, H., Zhang, Y., Li, X., Meng, Y., Liu, C., Zou, D., Liu, Y., 2014 Effects of ammoniation pretreatment at low moisture content on anaerobic digestion performance of rice straw. BioRes. 9(4), 67076718

[95] Zhang, H., Ning, Z., Khalid, H., Zhang, R., Liu, G., Chen, C., 2018. Enhancement of methane production from cotton stalk using different pretreatment techniques. Sci. Rep. 8, 3463.

[96] Zheng, Y., Zhao, J., Xu, F., Li, Y., 2014. Pretreatment of lignocellulosic biomass for enhanced biogas production. Prog Energy Combust. Sci. 42, 35-53.

[97] Zieminski, K., Kowalska-Wentel, M., 2017. Effects of different sugar beet pulp pretreatments on biogas production efficiency. Appl. Biochem. Biotechnol. 181(3), 12111227. 